АСПЕКТИ ПРОЯВУ ВПЛИВУ ПУБЛІЧНОГО УПРАВЛІННЯ Й АДМІНІСТРУВАННЯ НА ФУНКЦОНУВАННЯ ЗАЛІЗНИЧНОЇ ГАЛУЗІ

\title{
ASPECTS OF MANIFESTATION OF THE INFLUENCE OF PUBLIC ADMINISTRATION ON THE FUNCTIONING OF THE RAILWAY INDUSTRY
}

Вибір правлячим суб'єктом системи та механізмів публічного управління й адміністрування соціально-економічних орієнтирів розвитку держави багато в чому $є$ визначальним фрактором розвитку національної економіки. Статтю присвячено розкриттю аспектів прояву впливу вітчизняної системи публічного управління й адміністрування на функціонування залізничної галузі в різних економіко-правових умовах господарювання. Авторами проведено огляд публікацій щодо аспектів прояву впливу вітчизняної системи публічного управління й адміністрування на ффункціонування залізничної галузі. Дослідження показало, що більшість робіт з означеної проблематики присвячено теоретико-методологічним засадам орормування системи публічного управління й адміністрування залізничного транспорту, а також особливостям системи державного регулювання розвитком галузі. Матеріали статmі містять обірунтування типологізації організацій за критерієм мети їх створення. А саме: комериійні - створюються власниками задля отримання прибутку; публічні - створюються задля упорядкування життєдіяльності суспільства як єдиної цілісної системи, а також третій вид організацій mi, що створені як державні або комунальні, слугують державі інструментом вирішення соціальних питань і функціонують на комерчійних засадах. На прикладі залізничної галузі описано, яким чином держава вирішує соціально значимі проблеми, які вона обирає за пріоритетні напрями сочіально-економічного розвитку. Описано причини та наслідки надання пасажирським перевезенням статусу «соціально значимих», а також статусу «стратегічно важливих» перевезенням окремим родам вантажів. На прикладі приміського пасажирського залізничного сполучення розкрито перелік позитивних екстерналій, що отримує суспільство через прояви впливу на фрункціонування залізничної галузі наявної нині системи публічного управління й адміністрування. Обгрунтовано, що за сьогоднішніх економічних і суспільно-політичних умов єдиним шляхом вирішення проблем функціонування залізничного транспорту та подолання негативних екстерналії, які виникають як наслідок впливу системи публічного управління й адмініструванняна фуннціонування залізничної галузі, $є$ проведення його реформування з метою створення внутрішньогалузевої конкуренції та залучення приватного капіталу до участі в перевізному процесі. Це, у свою чергу, створить умови для підвищення ефективності роботи галузі загалом і нормалізації балансу екстерналій.

Ключові слова: державне регулювання, публічне управління i адміністрування, публічні організації, комерційні організації, залізничний транспорт, ресрормування, пасажирські перевезення, вантажні перевезення.

The choice of the governing subject of the system and mechanisms of public administration and administration of socio-economic landmarks of the state development is in many respects a determining factor of development of the national economy. The article is devoted to revealing aspects of the manifestation of the influence of the domestic system of public administration on the functioning of the railway industry in different economic and legal conditions of management. The authors reviewed the publications on aspects of the manifestation of the influence of the domestic public administration and administration system on the functioning of the railway industry. The research has shown that most of the works on this issue are devoted to theoretical and methodological principles of the formation of the system of public administration of railway transport, as well as features of the system of state regulation of the development of the industry. The article contains substantiation of the typology of organizations according to the criterion of their purpose of creation. Namely: commercial - created by owners for profit; public - created to streamline the life of society as a single holistic system, as well as a third type of organizations - those created as a state or communal and serving the state as a tool for solving social issues, while operating on a commercial basis. The example of the railway industry describes how the state solves socially significant problems that it selects for priority areas of socio-economic development. The reasons and consequences of passenger transportation status of "socially significant" and transportation of certain cargos of the status of "strategically important". The example of a suburban passenger rail service reveals a list of positive externalities that a society receives through manifestations of influence on the functioning of the railway industry of the current system of public administration. It is substantiated that in today's economic and socio-political conditions, the only way to solve the problems of railway transport functioning and to overcome the negative externalities arising as a result of the influence of the public administration system on the functioning of the railway industry is to carry out its reform in order to create internal competition private capital to participate in the transportation process. This, in turn, will create conditions for improving the efficiency of the industry as a whole and normalizing the balance of externalities.

Key words: state regulation, public administration, public organizations, commercial organizations, rail transport, reform, passenger transportation, freight.
Постановка проблеми у загальному вигляді. Як відомо, політичний курс держави $€$ концентрованим виразом економічних інтересів суспільства. Від того, наскільки правильно обрані пріоритети суспільно-економічного розвитку, залежить ступінь економічного розвитку держави. Це є важливим, бо лише держава з сильною економікою $є$ успіш- 
ною на міжнародній арені, що є визначальним фактором її національної безпеки. Сьогодні жодна з країн не перебуває в умовах чистої ринкової економіки. Всі провідні економіки світу - це економічні системи, де діють ринкові принципи господарювання та здійснюється публічне управління й адміністрування з метою зменшення та подолання негативних проявів ринку (монополізації ринків, розгорнення економічних криз тощо) як на загальнодержавному рівні, так і в окремих галузях, регіонах тощо.

Аналіз останніх досліджень і публікацій. Вперше принципи ринкової економіки було викладено в роботі А. Сміта [1]. Надалі ціла плеяда науковців-економістів підхопила ці дослідження та розвинула їх. Процес поглиблення знань про ринок і різноманіття взаємодії на ньому суб'єктів публічного управління й адміністрування із суб'єктами господарювання триває з часів Сміта досі.

Науковці, фахівці та практики залізничної галузі: О.Г. Дейнека, Л.О. Позднякова, В.Л. Дикань, А.Л. Каплієнко, Г.Є. Островерх, В.В. Матвієнко та ін., досліджуючи аспекти прояву впливів системи публічного управління й адміністрування на функціонування залізничного транспорту, свої роботи присвятили багатьом проблемним аспектам. Так, у роботі [2] авторами розкрито теоретичні підходи до державного управління й адміністрування залізничного транспорту України. Роботу [3] присвячено пошуку шляхів реформування ПАТ «Укрзалізниця» на базі вивчення досвіду залізничних адміністрацій країн Європи. Велику кількість робіт присвячено особливостям системи державного регулювання розвитком залізничної галузі [4-7].

Виділення невирішених раніше частин загальної проблеми. Незважаючи на велике розмаїття робіт щодо реалізації державного регулювання залізничної галузі й управління нею, лишається маловисвітленим питання щодо аспектів прояву впливу публічного управління й адміністрування на функціонування залізничної галузі за різних економіко-правових умов господарювання.

3 огляду на це метою публікації цієї статті $€$ розкриття аспектів прояву впливу публічного управління й адміністрування на функціонування залізничної галузі за різних умов господарювання.

Виклад основного матеріалу. Економіку будь-якої держави, незважаючи на форму правління нею, політичний режим та устрій, завжди створюють організації. Перші створюють додаткову вартість продукту, що реалізується і приносить прибуток, другі упоряд- ковують функціонування держави на макро-, мікрорівнях, а також на міжнародній арені.

Таким чином, всі організації, що функціонують у будь-якій державі світу, можна класифікувати за критерієм мети їх створення на комерційні та публічні. Комерційні - такі, що виникають в економіці з метою отримання власниками прибутку. Публічні - такі, що ставлять за мету упорядкування життєдіяльності суспільства як єдиної цілісної системи. Найбільш розповсюдженими групами публічних організацій $є$ органи державної влади та місцевого самоврядування. Але не варто забувати і про такі групи публічних організацій, як громадянські рухи, політичні партії тощо.

Можна виокремити також і третій вид організацій. 3 одного боку, їх головна мета - отримання прибутку. I вони, на перший погляд, цілком відповідають за своєю суттю комерційному типу організацій. Але, перебуваючи (найчастіше) в повній державній або комунальній власності, вони слугують державі інструментом вирішення соціально значимих питань.

Прикладом організацій такого видує АТ «Укрзалізниця». Тривалий час свого існування залізнична галузь виконує т. зв. роль «соціального перевізника». Статус «соціально значимих» стосується транспортних послуг із перевезень як вантажів, так і пасажирів.

У вантажному сполученні $є$ певний перелік вантажів, перевезення яких держава визначає як «стратегічні». До цієї категорії потрапляють перевезення переважно паливно-мастильних вантажів, хлібних тощо. Перевезення такого роду вантажів підлягає посиленому адмініструванню на загальнодержавному рівні. На регіональні філії залізниці накладається вимога здійснювати такі перевезення за низькорентабельними тарифами, а подеколи за тарифами майже з нульовою рентабельністю. Адмініструється процес тарифоутворення Антимонопольним комітетом, який відповідно до нині чинного законодавства погоджує тарифи на надання регіональними філіями Укрзалізниці транспортних послуг із перевезень вантажів і пасажирів, окрім перевезень пасажирів у приміському сполученні.

У пасажирському сполученні ситуація ще гірша. Так, загальна збитковість від надання транспортних послуг із перевезень пасажирів залізницею становить близько 30\%, зокрема у приміському сполученні - 70\% і більше. Тарифоутворення адмініструється Антимонопольним комітетом у далекому та місцевому сполученнях, а у приміському тарифи встановлюються за погодження з місцевою владою.

3 вищеописаного випливає низка питань. Чому держава так активно впливає на тран- 
спортні послуги залізниць із перевезень вантажів і пасажирів? Чому вона майже примушує залізниці виконувати роботу, що приносить їй такі разючі збитки? I чому залізниці, як будь-який свідомий суб'єкт господарювання, не мають змоги зовсім відмовитися від неприбуткового виду робіт?

Відповідь проста і лежить на поверхні. Джерело такого стану полягає у праві власності на виробничі відносини. Тривалий час залізнична галузь у повному обсязі перебувала у повній державній власності. Головна мета держави - упорядкування життя в суспільстві. Маючи у повній державній власності підприємства та структурні підрозділи залізничної галузі, держава довго використовувала їх як інструмент досягнення власних цілей: розв'язання соціально значимих питань, які обирала за пріоритетні.

Найразючіша збитковість - у приміському сполученні. Хто ним користується найчастіше? Це люди, які живуть у передмісті. Відповідно до обставин соціально-економічного розвитку продуктивних сил в Україні, чим менше населений пункт, тим менше в ньому робочих місць загалом, а високооплачуваних тим паче. у сільській місцевості робочих місць зовсім обмаль. Тому люди вимушені щодня прямувати на роботу на значні відстані. Переважна більшість приміського пасажиропотоку - це працівники, котрі щодня прямують на роботу до великого міста.

I держава свідомо йде на надання відносно недорогих перевезень у приміському сполученні, які дозволяють людям самопрацевлаштовуватися. Таким чином, позитивні екстерналії мають:

- роботодавці - власники підприємств, котрі отримують відносно недорогу робочу силу з передмістя, що знижує собівартість виготовленої ними продукції та підвищує конкурентоспроможність підприємств;

- мешканці передмість, які отримують можливість щоденної трудової міграції за невеликі кошти, забезпечуючи собі трудові доходи в теперішній час і соціальні гарантії у майбутньому;

- держава, що таким чином впливає на самопрацевлаштування працездатного населення, чим покращує соціальну вдоволеність суспільства, менше витрачає коштів соціальної допомоги у вигляді субсидій, допомоги малозабезпеченим і непрацевлаштованим, натомість отримує як доходи податки від роботодавців-власників підприємств, які утримують робочу силу з передмістя.

Негативні ж екстерналії отримує залізнична галузь, що через таку політику держави вимушена нести разючі збитки, покриваючи їх за рахунокприбутковихвантажнихперевезень.

Майже за таким самим сценарієм здійснюється регулювання тарифоутворення у секторі вантажних перевезень. Держава шляхом адміністрування через Антимонопольний комітет утримує низькорентабельні тарифи на перевезення окремих категорій вантажів, які вважає за «стратегічно значимі» для економіки загалом. Це дає змогу державі стримувати зростання кінцевої споживчої ціни товарів та / або послуг, що використовують у своєму складі як сировину ці вантажі.

Описаний стан спричиняє неспроможність галузі до оновлення виробничої бази, впровадження нових технічних та інформаційних засобів, рухомого складу тощо. Саме дляподолання вищеописанихнегативнихявищ розпочато та триває реформування залізничної галузі, яке має проводитися з метою розділення центрів управління інфраструктурою та перевізним процесом, виведення з державної власності сектору перевезень і залучення до нього приватного капіталу, створення компаній-перевізників; надання рівного доступу до послуг залізничної інфраструктури перевізникам усіх форм власності.

Саме умови конкуренції будуть мотивувати та спонукати компанії-перевізники вантажного сектору (де в майбутньому мають створюватися компанії на основі приватного капіталу), а також компанії пасажирського сектору (де компанії-перевізники мають створюватися на основі симбіозу приватної та державної власності, а в приміському секторі - також і муніципальної власності) до виконання своєї роботи більш ефективно. Держава, будучи співвласником компаній пасажирського сектору, має вирішувати межі доцільності надання пільг і дотацій за надання транспортних залізничних послуг із перевезення пасажирів.

Висновки. Проведене дослідження дає змогу усвідомити аспекти впливу вітчизняної системи публічного управління й адміністрування на функціонування залізничного транспорту в різних економіко-правових умовах господарювання галузі. Викладений матеріал обґрунтовує, що у сьогоднішніх економічних і суспільно-політичних умовах єдиним шляхом до вирішення проблем функціонування залізничного транспорту та подолання негативних екстерналії, що виникають як наслідок впливу системи публічного управління й адміністрування на функціонування залізничної галузі, $є$ проведення його реформування з метою створення внутрішньогалузевої конкуренції та залучення приватного капіталу до участі в перевізному процесі. Це, у свою 
чергу, створить умови для підвищення ефективності роботи галузі загалом і нормалізацію балансу позитивних і негативних екстерналій, що виникають внаслідок роботи залізничного транспортного комплексу.

\section{ЛIТЕРАТУРА:}

1. Сміт А. Багатство народів. Дослідження про природу та причини добробуту націй / пер. 3 англ. О. Васильєвої. Київ : Наш Формат, 2018. 722 с.

2. Дейнека О.Г., Каплієнко А.Л. Теоретичні підходи до державного управління і адміністрування залізничного транспорту України. Вісник економіки транспорту і промисловості. 2017. № 59. C. 224-230.

3. Дейнека О.Г., Позднякова Л.О. Зарубіжний досвід рефрормування залізничного транспорту в контексті публічного управління та адміністрування Укрзалізниці. Центр Інорормації транспорту України. URL: https://railway-publish.com/articles-icut- magazine/5566-zarubizhniy-dosvid-reformuvannyazaliznichnogo-transportu-v-konteksti-publichnogoupravlinnya-ta-administruvannya-ukrzaliznitsi.html.

4. Матвієнко В.В. Механізм державного управління розвитком залізничної галузі в Україні. Маріуполь : Донецький державний університет управління, 2017. 256 c.

5. Овчиннікова В.О. Особливості державного регулювання розвитку залізничного транспорту в Україні. Економіка $і$ суспільство економіка та управління національним господарством. 2017. № 12. C. 129-135.

6. Мохова Ю.Л. Стратегія розвитку державного регулювання залізничної галузі в Україні. Проблеми i перспективи економіки та управління.2016. № 3 (7). C. $90-95$.

7. Дикань В.Л., Островерх Г.Є. Удосконалення механізмів державного управління розвитком залізничної галузі України у євроінтеграційному векторі. Вісник економіки транспорту і промисловості. 2018. № 62. С. 11-19. 